International Journal of Biological Research, $2(1)(2014) 9-17$
International Journal of Biological Research
Journal home page: $\begin{gathered}\text { www.sciencepubco.com/index.php/IJBR } \\ \text { doi: } 10.14419 / \text { ijbr.v2il.1946 } \\ \text { Research Paper }\end{gathered}$

\title{
Effect of trichloroethylene (TCE) on female albino mice and their early embryos
}

\author{
El-Shershaby AM ${ }^{1}$, El-Balshy RM ${ }^{2}$, Abd El-Hady SI $^{2}$, Abou Rashed NM ${ }^{2 *}$ \\ ${ }^{1}$ Dept. of Zoology, Faculty of Science, Cairo University., Egypt \\ ${ }^{2}$ Dept. of Zoology, Faculty of Science, Benha University, Egypt \\ *Corresponding author E-mail: nagahabourashed76@gmail.com
}

\begin{abstract}
The present study investigates the effects of different doses of "trichloroethylene" TCE on pregnancy, early embryos on days 6 and 8 of pregnancy. The experimental females (90 virgin females) were divided into three groups; the first one (C) was the control that treated with the solvent only (corn oil), the second (G1) and the third (G2) treated groups with low (24 mg/kg) and high (240 mg/kg) dose of TCE, respectively. Oral administration of TCE to female mice once daily for a period of 21 days before mating and till $5^{\text {th }}$ and $7^{\text {th }}$ day of pregnancy, caused a significant decrease in the body weight for non-pregnant females and weight gain for pregnant females. The percentage of survival, mating and abortion were also significantly decreased by TCE treatment for pregnant females. Histological examination for the obtained 6 and 8 day mice embryos from treated mothers showed some histopathological alterations in compared with the normal control embryos. These alterations indicated that TCE treatment resulted in retarded, delayed and deformed embryos. The results suggest that TCE has teratogenic and embryo toxic effects on the early development of mice embryos following a short-term of exposure.
\end{abstract}

Keywords: Trichloroethylene, Mating, 6th and 8th Day Mouse Embryo, Histopathology, Early Developmental Stages.

\section{Introduction}

Trichloroethylene (TCE) is a chlorinated hydrocarbon, not naturally found in the environment (man-made); it is an environmental toxicant due to production, use and disposal. It is a colorless nonflammable liquid with a sweet odour. TCE is detectable in underground water sources, surface water, and the air (Ugden et al., 1983). TCE is produced in the petrochemical industry and has many uses, such as in dry cleaning operations, paint and printing ink removal, fumigation of rodents, manufacturing fluorocarbons, beverages (decaffeination of coffee), pet foods, medicine, pharmaceuticals, cosmetics and as an anesthetic agent (Kaneko et al., 1997; IARC, 1995; Maull et al., 1997). In addition, it is used in the pharmaceutical industry as a solvent for waxes, fats, resins, and oils and in the aerospace industry for flushing liquid oxygen. Trichloroethylene is readily absorbed following both oral and inhalation exposures. It is also absorbed from the gastrointestinal tract into the systemic circulation in animals. Using radiolabelled TCE, Mass balance studies indicated that mice and rats metabolized TCE at $38.10 \%$ and $15.10 \%$, respectively, following oral administration in corn oil vehicle. For both species, the lower values were obtained following treatment with large doses in excess of $1000 \mathrm{mg} / \mathrm{kg}$ bw, implying that the rate of absorption was higher at low doses than at high doses in both species (Mitoma et al., 1985; Prout et al., 1985 and Rouisse \& Chakrabarti, 1986). Once absorbed, TCE diffuses readily across biological membranes and is widely distributed to tissues and organs via the circulatory system. Studies in animals (Fernandez et al., 1977; Fisher et al., 1991) and humans (De Baere et al., 1997) have found TCE or its metabolites in most major organs and tissues. Also, TCE may accumulate in adipose tissue because of its lipid solubility. Consequently, slow release of TCE from adipose stores might act as an internal source of exposure, ultimately resulting in longer mean residence times and bioavailability of TCE (Dallas et al., 1991; Fisher et al., 1991). The oxidative metabolism of TCE occurs primarily in the liver, although it may also occur in other tissues, particularly the kidney and the lung. There are two main pathways responsible for TCE metabolism: oxidation by cytochrome P-450 and conjugation with glutathione (GSH) by glutathione-Stransferases (Lash et al., 2000). In the liver, TCE is metabolized to an electrophilic epoxide intermediate, which spontaneously rearranges to chloral. Chloral is further metabolized to trichloroethanol $(\mathrm{TCOH})$, trichloroethanol glucuronide (TCOG) and trichloroacetic acid (TCA). Other metabolites were mentioned including carbon dioxide, $\mathrm{N}$ (hydroxyacetyl) aminoethanol and oxalic acid (Goeptar et al., 1995).

\section{Materials and methods}

\subsection{Animals}

Ninety virgin female and thirty fertile male albino mice weighing approximately 23-25 gm were used for experimentation. The animals were arranged into three groups, each was composed of 30 females as follows: The first group (C), in which the animals were treated under the same condition with the dose solvent (corn oil). The second group (G1) and the third group (G2) in which females were treated orally for three weeks (daily) with $24 \mathrm{mg} / \mathrm{kg}$ and 240 $\mathrm{mg} / \mathrm{kg}$ body weight of TCE, respectively. The treated females allowed mating with normal male, and then the pregnant females received TCE on day 5 and 7 of gestation. 


\subsection{Mating procedures}

The females which were found at the pro-estrus stage were selected, each three of them were kept with one adult male in one cage overnight. Occurrence of copulation was established in the next morning at 9.00 a.m. by the presence of the vaginal plug and/or the presence of the sperms in the vaginal smear, and this day was considered to be the first day of pregnancy, assuming coitus took place at 1.0 a.m. on the night of mating (Terada and Nishimura, 1975). The treated pregnant females received TCE until 5th and 7 th day of gestation and sacrificed on days 6 and 8 of pregnancy.

\subsection{Administration of trichloroethylene}

Highest purity trichloroethylene (TCE) obtained from SigmaAldrich company at Cairo, two doses of TCE investigated in the present study were 24 and $240 \mathrm{mg} / \mathrm{kg}(1 / 100$ as low dose and $1 / 10$ of $\mathrm{LD}_{50}$ as a high dose, respectively) dissolved in corn oil. Control doses consist of corn oil only. The used doses were made up immediately preceding dosing and a volume of $0.2 \mathrm{ml}$ was given per animal. Mice were administered TCE using curved gavage needle attached to a graded glass syringe. Food was withheld from all animals for 4 hours prior to daily administration.

The treated pregnant females sacrificed at 6th and 8th day of gestation for extracting the whole uterus with 6 and 8 day mouse embryo, respectively. The uterus fixed in $10 \%$ neutral buffered formalin for $24 \mathrm{~h}$, washed, dehydrated, cleared, embedded, sectioned in $5 \mu \mathrm{m}$, stained with Ehrlichs heamatoxylin and eosin and mounted on a clean glass slides then examined.

\section{Results}

\subsection{Maternal body weight}

In this respect, the body weight was recorded at the end of the first, second and third week for TCE treated females before mating (non-pregnant females) as well as females of the control group (Table 1 and Fig. 1). At the end of the third week, the percent of body weight change for both groups (G1 and G2) was statistically significant compared to the control. After mating, the body weight of TCE treated pregnant females of each group was recorded every 6 days of gestation until day 18 of pregnancy. Most of the treated pregnant dams showed little increase in body weight throughout the three periods. However, the decrease in the body weight of the treated pregnant dams in comparison with the control pregnant was statically significant and is proportional with the duration and level of the used dose of TCE i.e. it was a dose and time dependent (Table 2 and Fig. 1). In addition, a significant decrease was observed in the body weight gain of the treated pregnant dams of groups G1 and G2 compared with the control pregnant mice especially at the end of day 12 and day 18 of gestation. The decrease in body weight gain of group G2 was significant compared to body weight gain of group G1.

\subsection{Survival of non-pregnant and pregnant treated fe- males}

The present study showed no deaths in the control group. However, females treated before mating showed that one female died from group G1 on the second week and two females died on the third week. While, five females were died from G2, one on the first week and four died on the second and third weeks (two dead females for each week). At the end of the treatment period, the percent of survival of females treated with the high dose of TCE (G2) was significantly decreased compared to the control. The percent of survival of females before mating for the control, G1 and $\mathrm{G} 2$ at the end of the third week of treatment was $100 \%, 90 \%$ and $76.7 \%$, respectively. In addition, the percent of survival of pregnant dams of the control group on day 18 of gestation was $100 \%$. However, the percent of survival of the treated pregnant females of groups G1 and G2 decreased to $95.2 \%$ and $85.7 \%$, respectively (Table 3 and Fig. 2).

\subsection{Percentage of mating}

Most of the treated females were symptomized by reduced excitability and appetite. At the end of the third week of treatment the virgin females allowed to mate with normal proven males. It was observed that the percent of mating for the treated females was less than the control. The percent of succeeded copulation was $96.7 \%, 77.8 \%$ and $60.9 \%$ for control, treated G1 and G2, respectively (Table 3 and Fig. 2).

\subsection{Percentage of abortion}

The present study showed that during the gestation period, one aborted dam from the first group (G1) that received low dose of TCE and three aborted dams from the second group (G2) that received high dose of TCE were recorded. However, the control group showed no aborted females. The abortion was confirmed by the presence of blood drops in the vagina and sudden loss in maternal body weight. The percent of abortion in the second group (G2) was more than that of the first group (G1) compared to the control where no aborted pregnant dams were noted (Table 4 and Fig. 3). The mean number of fetuses was markedly reduced in the treated groups compared to the control. The percent of reduction/mother was $11.89 \%$ and $30.95 \%$ for G1 and G2, respectively.

\subsection{Day 6 embryo (132 H.P.C.)}

\subsubsection{Low dose treatment}

Most of the examined embryos obtained from pregnant females treated with the low dose of TCE $(24 \mathrm{mg} / \mathrm{kg})$ were similar in their histoarcheticture to the control egg-cylinder of normal pregnancy. However, few embryos showed very little variations, which may not affect their normal development. A cylindrical embryo shown in Fig. 5 is consisted of a central mass of ectodermal cells, extraembryonic and embryonic cells. These cells appeared normal with eosinophilic cytoplasm and basophilic rounded nuclei. In the middle area of the ectodermal mass a few number of cells showed less eosinophilic cytoplasm and dense basophilic, probably, pyknotic nuclei. Some proximal endodermal cells at the lateral dorsal region of the egg-cylinder were spherical or flattened instead of being cuboidal or low columnar with moderately eosinophilic stained cytoplasm and dense basophilic nuclei around which halo spaces are seen. Several decidual cells around the embryo exhibited less eosinophilic cytoplasm, large dense basophilic nuclei and halo spaces. The plane of sectioning of this specimen may be somewhat oblique, so the proamniotic cavity was not observed and the ectoplacental cone appeared small and short.

Another cylindrical embryo was obtained in such condition of low treatment showing the entire embryonic layers described before in the control embryo. In this specimen, the embryonic cells were less eosinophilic and the nuclei were less basophilic. Several degenerated cells with pyknotic nuclei were shown in all layers of the embryo. The number of dead cells was increased than that observed in normal pregnancy. In addition, vacuolated decidual cells were demonstrated with shrinkage cytoplasm and pyknotic nuclei. Few deteriorated proximal endodermal cells were found at the dorso-lateral side of the embryo. In this specimen the proamniotic cavity was observed in the centre of the extraembryonic ectoderm indicating that the plane of sectioning in such case was also somewhat oblique (Fig. 6).

\subsubsection{High dose treatment}

Microscopical examination of sagittal sections in the mice embryos obtained from dams treated with the high dose of TCE (240 $\mathrm{mg} / \mathrm{kg}$ b.w.) for 21 days before mating and 7 days during pregnancy showed some deformed embryos with definide structures. The 
ectoplacental cone was undeveloped with indefinite cellular appearance. A large empty space was seen in its centre. Dead cells with pyknotic nuclei were observed in the extraembryonic ectoderm. They were more pronounced than in normal embryos. Also, vacuolated cells with shrinkage cytoplasm were evidented. The proximal endoderm looks normal at the mesometrial pole of the embryo and disrupted at the antimesometrial pole. The most striking feature in this specimen was the deformation of the embryonic ectoderm that will form the embryo proper. It comprised numerous vacuolated cells with small dense nuclei, dead and disintegrated embryonic cells at its luminal surface and somewhat wider proamniotic cavity. Small haemorrhagic patches were seen very near to the undeveloped ectoplacental cone and at the antimesometrial pole of the egg-cylinder (Fig. 7).

At the high dose level of TCE, some completely degenerated or destructed embryos were investigated (Fig. 8). The egg-cylinder is represented by an elongated mass of rounded cells and it was not easy to differentiate between the normal arrangements of the germ layers. Cells of the ectoplacental cone were basophilicaly stained and the normal porous appearance of these cells was disappeared. Vacuoles of different sizes and small haemorrhagic patches were also observed. Most of the endodermal cells were highly vacuolated with degenerated nuclei. The proximal endodermal cells were disorganized and appeared round in appearance and found around the circumference of the degenerated egg-cylinder. Some of these cells were degenerated with pyknotic and chromatolytic nuclei. The distal endodermal cells were ill-defined; some of them with pyknotic nuclei. The decidua around the embryo showed many degenerated round cells with large vacuoles and pyknotic nuclei. Phagocytic cells were observedin the deciduoma very near to the degenerated embryo. Large vacuoles or empty spaces were seen around the implanting embryo separating it from the surrounding deciduoma probably preventing the arrival of nourishment from the mother tissues at this stage of embryonic development.

\subsection{Day 8 embryo (180 H.P.C)}

\subsubsection{Low dose treatment}

In such case, normal cylindrical embryos were obtained showing similar structure to those obtained from the untreated female mice. These embryos showed normal ectoplacental cone, extraembryonic and embryonic ectoderm, a narrow chorionic cavity, chorionic membrane, exocoelom, allantois, amniotic membrane and amniotic cavity (Fig. 10). The mesoderm was found around the embryonic ectoderm and extends upwards, bluging into the exocoelom to form the anterior amniotic fold. The distal endoderm and trophectoderm were observed adjacent to the decidual tissue. Other cylindrical embryos obtained from pregnant mothers treated for 21 days before pregnancy and for 7 days during pregnancy with low dose of TCE ( $24 \mathrm{mg} / \mathrm{kg}$ b.w.) showed some variations in the form and structure from the normal (control) embryos (Fig. 11). Two main cavities were observed in some embryos, exocoelomic and proamniotic cavities. This embryo was considered to be retarded than that obtained from normal pregnancy. It showed necrotic mass of cells in the extraembryonic region. This mass displayed highly vacuolated cells and cell remnants. Large densely stained cells probably phagocytes were also present. Most probably, this necrotic mass comprised degenerated cells from the proximal endoderm and the adjacent extraembryonic ectoderm. Few degenerated cells were seen in the yolk-sac cavity between the proximal and distal endoderm (Figs. 11\&12).

The embryonic ectoderm showed numerous vacuolated cells with dense nuclei, the mesoderm was consisted of dispersed unidentifiable cells found at one lateral side of the embryonic ectoderm and not around it. This picture was not found in a comparable stage of normal pregnancy. Dissociated and disrupted proximal endodermal cells were found mainly at the junction between the extraembryonic and embryonic ectoderm. The decidua around the embryo looks normal and pools of maternal blood were shown. Some decidual cells were vacuolated with densely stained nuclei (Fig. 11).

\subsubsection{High dose treatment}

Examination of 71/2-day embryos (180h p.c.) obtained from pregnant mice treated previously before mating for 21 days and during pregnancy for 7 days with high dose of TCE (240 mg/kg b.w.) showed that most embryos are of normal histoarchitecture as those obtained from normal pregnancy (Fig. 9). However, retarded, deformed and sometimes degenerated embryos were also demonstrated. Figure 13 illustrates a retarded embryo, the structure of which represents a stage of development between day 6 and day 8 of pregnancy. The ectochorionic cavity was separated from the proamniotic one by a thick layer of the embryonic ectoderm. The exocoelomic cavity and the allantois were absent. The mesoderm was found at the junction between the extraembryonic and embryonic ectoderm, extending downwards between the embryonic ectoderm and the proximal endoderm. Several embryonic ectodermal cells showed vacuoles and dense pyknotic nuclei. Cells of the ectoplacental cone were highly vacuolated and the underneath extraembryonic ectoderm showed disorganized cells. Large densely stained cells were observed in the decidua around the embryo probably representing phagocytes. The blood islands found around normal embryos at this stage of development were absent.Some other egg-cylinders obtained from high dose TCE treatment exhibited a deformed structure (Fig. 14). Again, the general architecture of the egg-cylinder represents a stage of development before day 8 of normal pregnancy. The histological appearance of this embryo showed unidentifiable layers and cells. The ectoplacental cone is represented by a small group of cells found at the mesometrial pole of the embryo. Abnormal tongue like-structure from the proximal endoderm consisted of degenerated cells was seen in the dilated yolk-sac cavity. The extraembryonic and embryonic ectoderms were consisted of disorganized cells. The mesodermal cells appeared at one side of the embryo and extending downwards. The posterior amniotic fold was not fully expanded within which small exocoelomic cavity was present. The decidual cells displayed eosinophilic cytoplasm and dense nuclei, some cells showed up to four nuclei in the cytoplasm. Maternal blood was not found around the deformed embryo.Other embryos showed densely stained undistinguishable layers and cells. In such case, the embryo had lost its characteristic histological features. Most cells were dead or dying with very dense pyknotic nuclei (Fig. 15). Two cavities were present in this embryo representing the ectoplacental cone and proamniotic cavities. In the decidua, many vacuolated cells with dense nuclei were recognized and some large cells probably phagocytes were observed. Heamorrhagic patches were shown around this embryo; probably represent an initial stage of abortion. 
Table 1: Relative percentage of body weight change for non-pregnant control and treated females with TCE.

\begin{tabular}{|c|c|c|c|c|c|c|c|c|c|}
\hline \multirow{2}{*}{ Groups } & \multicolumn{7}{|c|}{$\begin{array}{l}\text { Weight of females before mating } \\
\text { End of } 1^{\text {st }} \text { week }\end{array}$} & \multicolumn{2}{|c|}{ End of $3^{\text {rd }}$ weeks } \\
\hline & No. of females & Mean \pm SD & $\%$ of change & Mean \pm SD & $\%$ of change & Mean \pm SD & $\%$ of change & Mean $\pm \mathrm{SD}$ & $\%$ of change \\
\hline $\mathrm{C}$ & 30 & $32.0 \pm 0.40$ & 0 & $32.6 \pm 0.32$ & 1.88 & $33 \pm 0.32$ & 3.13 & $33.9 \pm 0.32$ & 5.94 \\
\hline G1 & 30 & $32.0 \pm 0.28$ & 0 & $31.1 \pm 0.26$ & 2.81 & $30.2 \pm 0.26^{*}$ & 5.63 & $28.8 \pm 0.26 * *$ & 10.00 \\
\hline G2 & 30 & $32.0 \pm 0.21$ & 0 & $30.2 \pm 0.19 *$ & 5.63 & $28.9 \pm 0.19 * *$ & 9.67 & $26.7 \pm 0.19 * *$ & 16.56 \\
\hline
\end{tabular}

Table 2: Relative percentage of body weight change for pregnant control and treated females with TCE.

\begin{tabular}{|c|c|c|c|c|c|c|c|c|c|}
\hline \multirow[b]{3}{*}{ Groups } & \multicolumn{7}{|c|}{ Weight of pregnant females (after mating) } & \multirow{2}{*}{\multicolumn{2}{|c|}{ End of $18^{\text {th }}$ day }} \\
\hline & \multicolumn{3}{|c|}{$1^{\text {st }}$ Day } & \multicolumn{2}{|c|}{ End of $6^{\text {th }}$ day } & \multicolumn{2}{|c|}{ End of $12^{\text {th }}$ day } & & \\
\hline & $\begin{array}{l}\text { No. of preg- } \\
\text { nant females }\end{array}$ & Mean \pm SD & $\begin{array}{c}\% \text { of } \\
\text { change }\end{array}$ & Mean \pm SD & $\begin{array}{l}\% \text { of } \\
\text { change }\end{array}$ & Mean \pm SD & $\begin{array}{l}\% \text { of } \\
\text { change }\end{array}$ & Mean \pm SD & $\%$ of change \\
\hline $\mathrm{C}$ & 29 & $33.6 \pm 0.42$ & 0 & $35.9 \pm 1.22$ & 6.9 & $39.6 \pm 1.22$ & 17.21 & $42.1 \pm 1.22$ & 25.3 \\
\hline G1 & 20 & $28.4 \pm 0.75$ & 0 & $30.9 \pm 2.04 *$ & 8.8 & $32.3 \pm 2.04 *$ & 13.3 & $33.2 \pm 2.04 * *$ & 16.55 \\
\hline $\mathrm{G} 2$ & 12 & $26.1 \pm 0.85$ & 0 & $27.2 \pm 2.01 *$ & 4.2 & $28.4 \pm 2.01 * *$ & 8.6 & $29.5 \pm 2.01 * *$ & 12.5 \\
\hline
\end{tabular}

Table 3: The percentage of survival and mating of control and treated females with TCE.

\begin{tabular}{|c|c|c|c|c|c|c|c|c|c|c|c|c|}
\hline \multirow[b]{2}{*}{ Groups } & \multirow[b]{2}{*}{$\begin{array}{c}\text { No. of } \\
\text { females }\end{array}$} & \multicolumn{4}{|c|}{$\begin{array}{l}\% \text { of survival } \\
\text { Before mating (non-pregnant) }\end{array}$} & $3^{\text {rd }}$ & reek & & of mating & & \multicolumn{2}{|c|}{$\begin{array}{c}\% \text { of survival } \\
\text { After mating } \\
\text { (pregnant) }\end{array}$} \\
\hline & & $\begin{array}{c}\text { No. of } \\
\text { dead } \\
\text { females }\end{array}$ & $\begin{array}{c}\text { Percent } \\
(\%)\end{array}$ & $\begin{array}{l}\text { No. of } \\
\text { dead } \\
\text { females }\end{array}$ & $\begin{array}{c}\text { Percent } \\
(\%)\end{array}$ & $\begin{array}{l}\text { No. of } \\
\text { dead } \\
\text { females }\end{array}$ & $\begin{array}{c}\text { Percent } \\
(\%)\end{array}$ & $\begin{array}{c}\text { No. of } \\
\text { survival } \\
\text { females }\end{array}$ & $\begin{array}{l}\text { No. of } \\
\text { pregnant } \\
\text { females }\end{array}$ & $\begin{array}{c}\% \text { of } \\
\text { mating }\end{array}$ & $\begin{array}{l}\text { No. of } \\
\text { dead } \\
\text { females }\end{array}$ & $\begin{array}{c}\text { Percent } \\
(\%)\end{array}$ \\
\hline $\mathrm{C}$ & 30 & 0 & 100 & 0 & 100 & 0 & 100 & 30 & 29 & 96.7 & 0 & 100 \\
\hline G1 & 30 & 0 & 100 & 1 & 96.7 & 2 & 90.0 & 27 & 21 & 77.8 & 1 & 95.2 \\
\hline
\end{tabular}

Table 4: Effect of TCE on Some Maternal and Foetal Measurements throughout the Gestation Period

\begin{tabular}{|c|c|c|c|c|c|c|c|c|c|c|c|}
\hline groups & $\begin{array}{c}\text { No. of } \\
\text { pregnant } \\
\text { females }\end{array}$ & $\begin{array}{c}\text { No. of } \\
\text { females } \\
\text { with } \\
\text { alive } \\
\text { foetuses }\end{array}$ & $\begin{array}{l}\text { No. of } \\
\text { aborted } \\
\text { females }\end{array}$ & $\begin{array}{c}\% \text { of } \\
\text { Aborted } \\
\text { females }\end{array}$ & $\begin{array}{c}\text { Total } \\
\text { no. of } \\
\text { foetuses }\end{array}$ & $\begin{array}{c}\text { No. of } \\
\text { alive } \\
\text { foetuses }\end{array}$ & $\begin{array}{c}\text { No. of } \\
\text { dead } \\
\text { foetuses }\end{array}$ & $\begin{array}{c}\% \text { of } \\
\text { resorbed } \\
\text { foetuses }\end{array}$ & $\begin{array}{c}\text { Mean No. } \\
\text { of foetuses } \\
\text { / mother }\end{array}$ & $\begin{array}{c}\% \text { of } \\
\text { foetuses } \\
\text { / mother }\end{array}$ & $\begin{array}{l}\% \text { of reduc- } \\
\text { tion/mother }\end{array}$ \\
\hline $\mathrm{C}$ & 29 & 29 & 0 & 0 & 202 & 202 & 0 & 0 & $6.98 \pm 0.41$ & 100 & 0 \\
\hline G1 & 20 & 17 & 1 & 5 & 117 & 104 & 13 & 4.3 & $6.15 \pm 0.23$ & 88.11 & 11.89 \\
\hline G2 & 12 & 8 & 3 & 25 & 58 & 41 & 17 & 19 & $\begin{array}{c}4.82 \pm \\
1.55 * *\end{array}$ & 69.05 & 30.95 \\
\hline
\end{tabular}

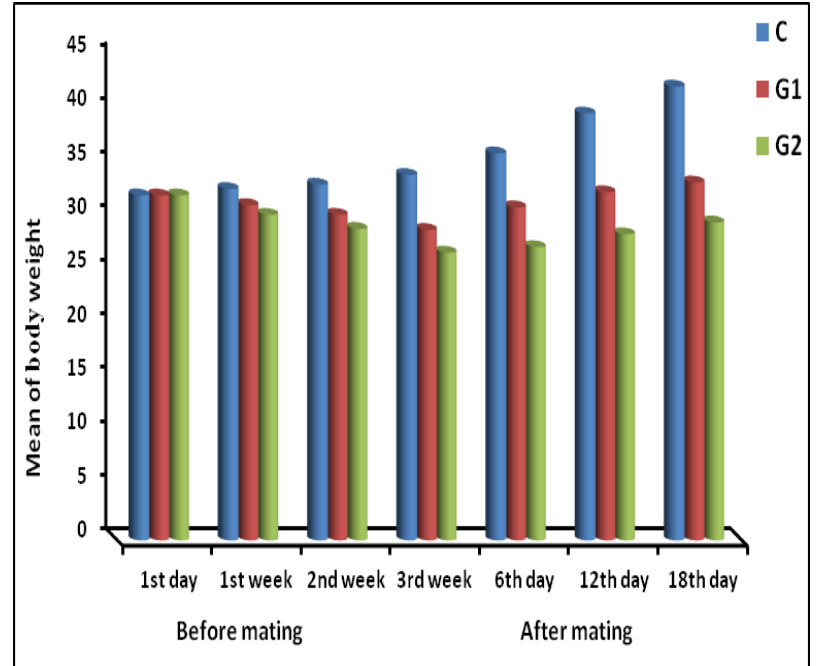

Fig. 1: Body Weight Change for Non-Pregnant and Pregnant Control and Treated Females with TCE.

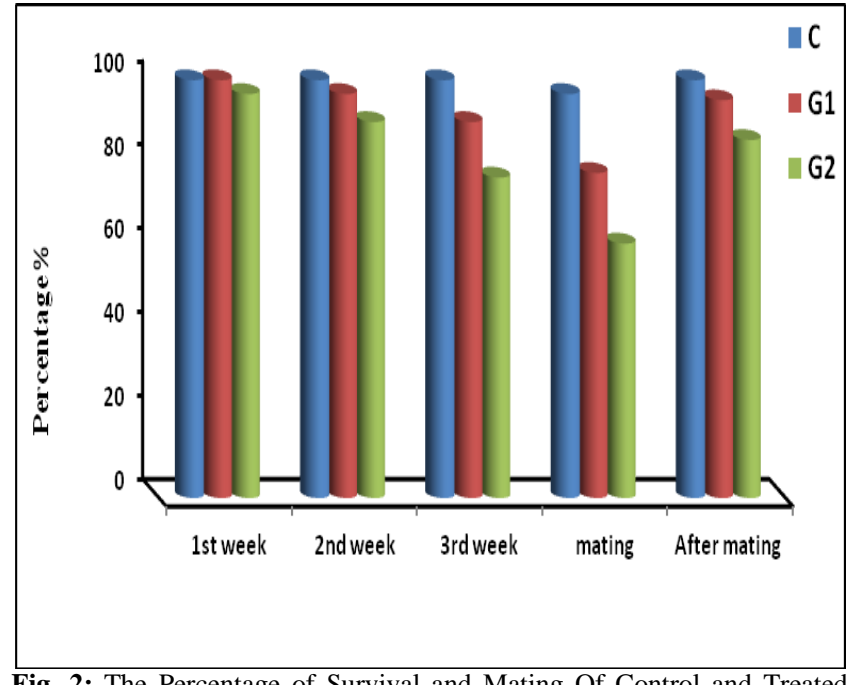

Fig. 2: The Percentage of Survival and Mating Of Control and Treated Females with TCE. 


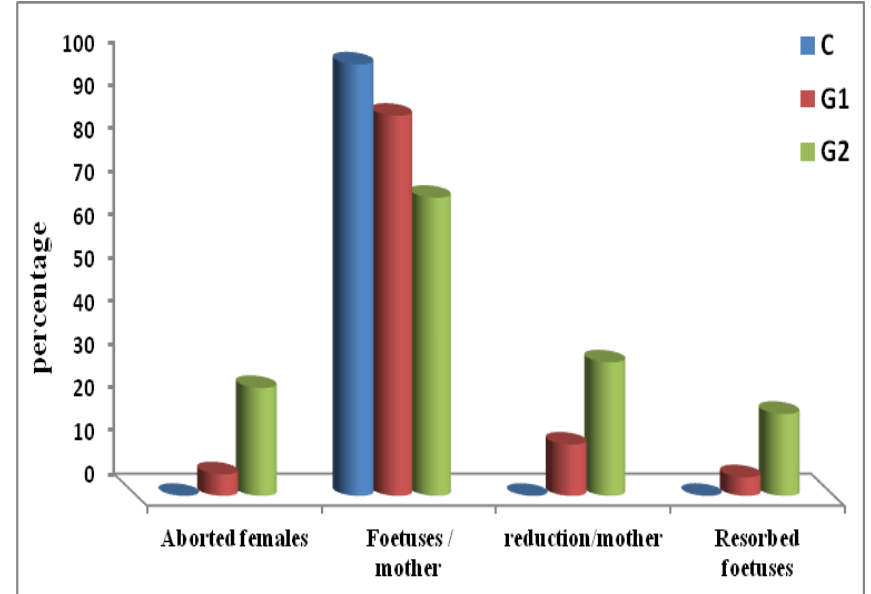

Fig. 3: The Percent of Aborted Females, Foetuses/Mother, Reduction/Mother and Resorbed Foetuses of Control and Treated Females with TCE.

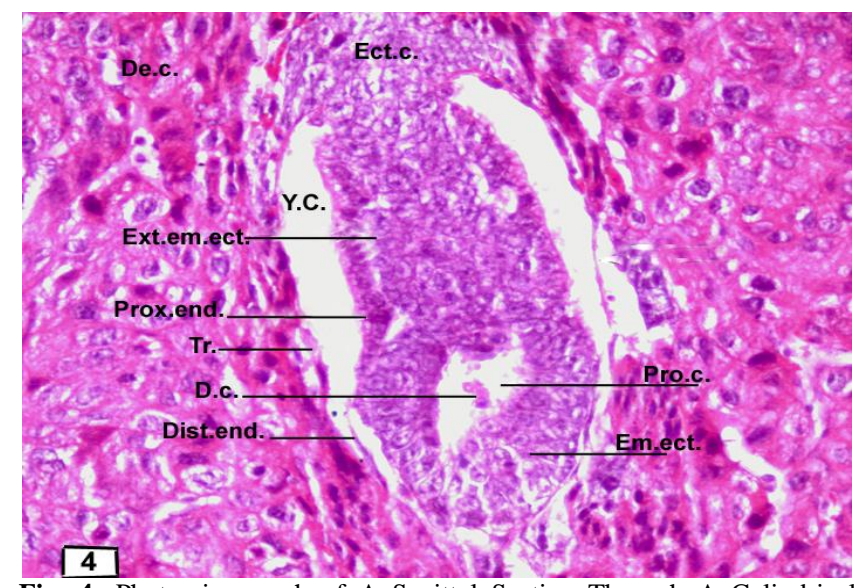

Fig. 4: Photomicrograph of A Sagittal Section Through A Cylindrica Embryo Of A Mouse At 132h P.C. Stained with (H \& E) Showing Normal Histoarchitecture of the Embryo. Ectoplacental Cone (Ect.C.) Extraembryonic Ectoderm (Ext.Em.Ect.), Embryonic Ectoderm (Emb.Ect.), Proamniotic Cavity (Pro.C.), Proximal Endoderm (Prox.End.), Distal Endoderm (Dist.End.), Yolk-Sac Cavity (Y.C.), Trophectoderm (Tr.), Dead Cells (D.C.), Decidual Cells (De.C.).

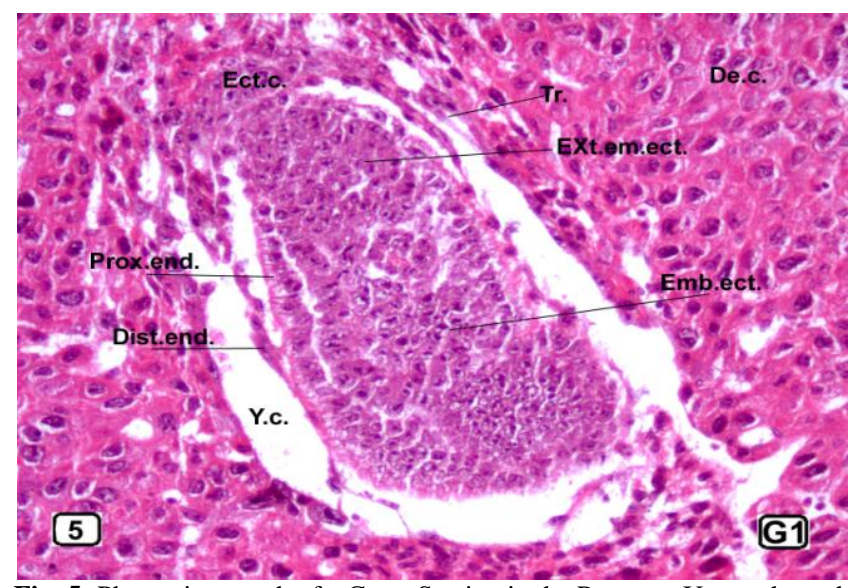

Fig. 5: Photomicrograph of a Cross Section in the Pregnant Uterus through a Cylindrical Embryo of a Mouse Treated with Low Dose of TCE Showing More or Less Normal Embryo with Well-Defined Layers

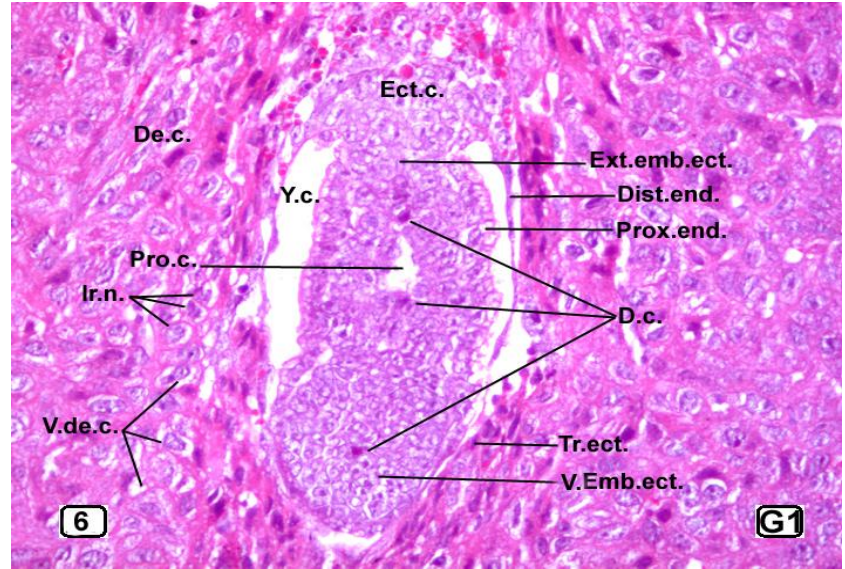

Fig. 6: Photomicrograph of a Sagittal Section Through a Cylindrical Embryo of a Mouse at 132h P.C. Treated With Low Dose of TCE Showing More or Less Normal Embryo With Several Vacuolated Embryonic Ectodermal Cells (V.Emb.Ect.), Dead Cells (D.C.), Vacuolated Decidual Cells (V.De.C.) with Irregular Nuclei (Ir.N.), the Proamniotic Cavity (Pro.C.) Appears in the Extraembryonic Ectoderm (Ext.Em.Ect.).

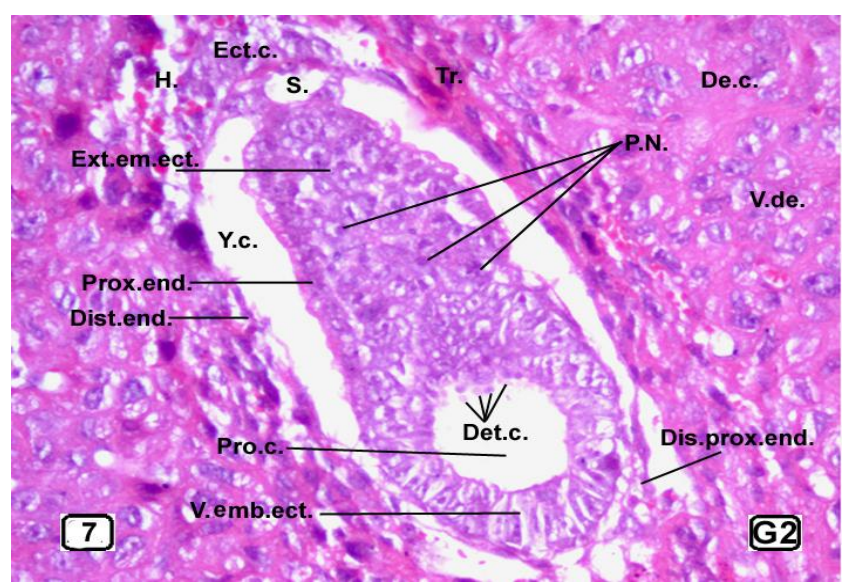

Fig. 7: Photomicrograph of a Sagittal Section Through a Cylindrical Embryo of a Mouse Treated With High Dose of TCE Showing a Probable Deformed Embryo With More or Less Normal Extraembryonic Ectoderm (Ext.Em.Ect.), Highly Vacuolated Embryonic Ectodermal Cells (V.Emb.Ect.) Some of Them with Pyknotic Nuclei (P.N.), Disrupted Proximal Endodermal Cells (Dis.Prox.End.), Wide Proamniotic Cavity (Pro.C.) with Several Deteriorated Cells (Det.C.), Undeveloped Ectoplacental Cone (Ect.C.), with Large Space In The Middle (S.), Haemorrhage (H.), Many Disrupted and Vacuolated Decidual Cells (V.De.C.).

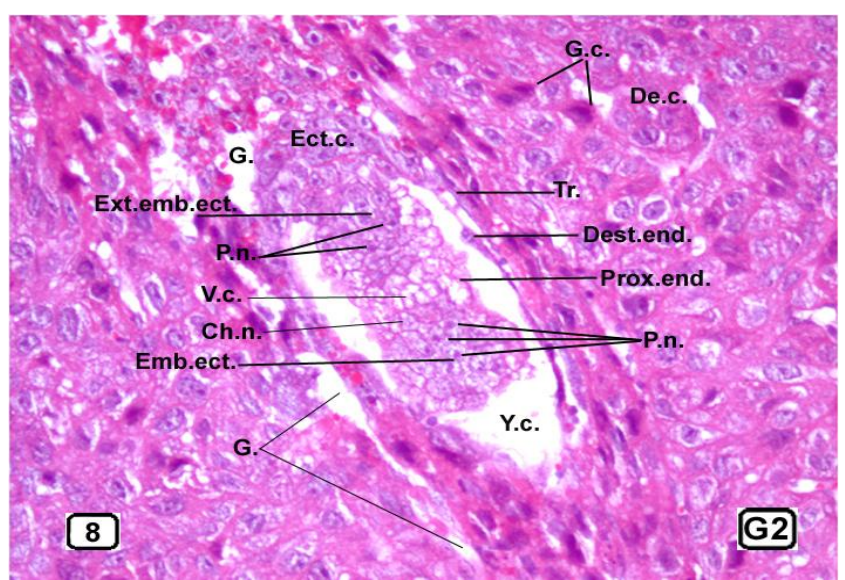

Fig. 8: Photomicrograph of a Sagittal Section Through a Cylindrical Embryo of a Mouse Treated With High Dose Of TCE Showing Small Sized Degenerated Embryo With Disorganized Layers, Numerous Vacuolated Cells (V.C.) With Pyknotic (P.N.) and Chromatolytic Nuclei (Ch.N.), Numerous Degenerated Decidual Cells (De.C.) With Shrinkage Cytoplasm and Pyknotic Nuclei, Giant Cells (G.C.), Gaps are seen in the Decidua (G.) Around The Embryo. 


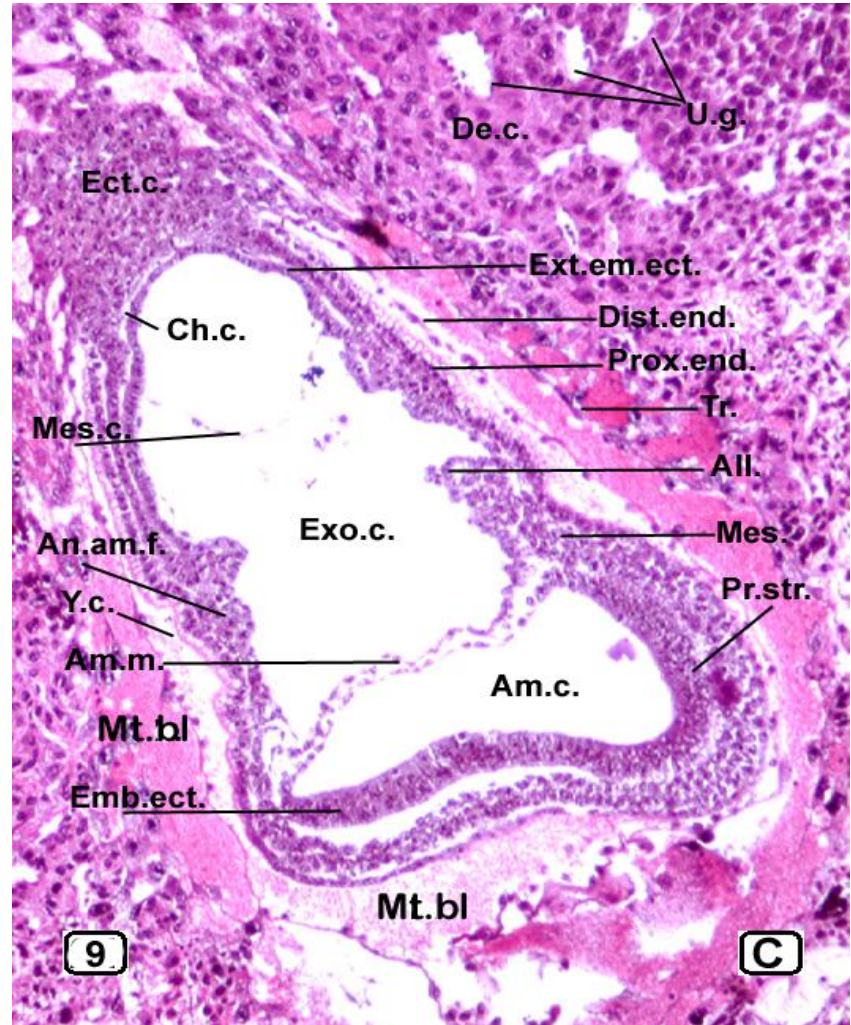

Fig. 9: Photomicrograph of a Sagittal Section Through a Cylindrical Embryo of a Mouse at 180 h P.C. Stained With (H \& E) Showing Developed Ectoplacental Cone (Ect.C.), Invaginated Extraembryonic Ectoderm (Ext.Em.Ect.), Embryonic Ectoderm (Emb.Ect.), Primitive Streak (Pr.Str.), Mesoderm (Mes.), Anterior Amniotic Fold (An.Am.F.), Exocoelomic Cavity (Exo.C.), Remnant of Ectochorionic Cavity (Ect.C.C.), Amniotic Cavity (Am.C.), Allantois (All.), Amniotic Membrane (Am.M.), Proximal Endoderm (Prox.End.), Distal Endoderm (Dist.End.), Trophectoderm (Tr.), Decidua (Dec.), Maternal Blood (Mt.Bl.), Uterine Glands (U.G.)

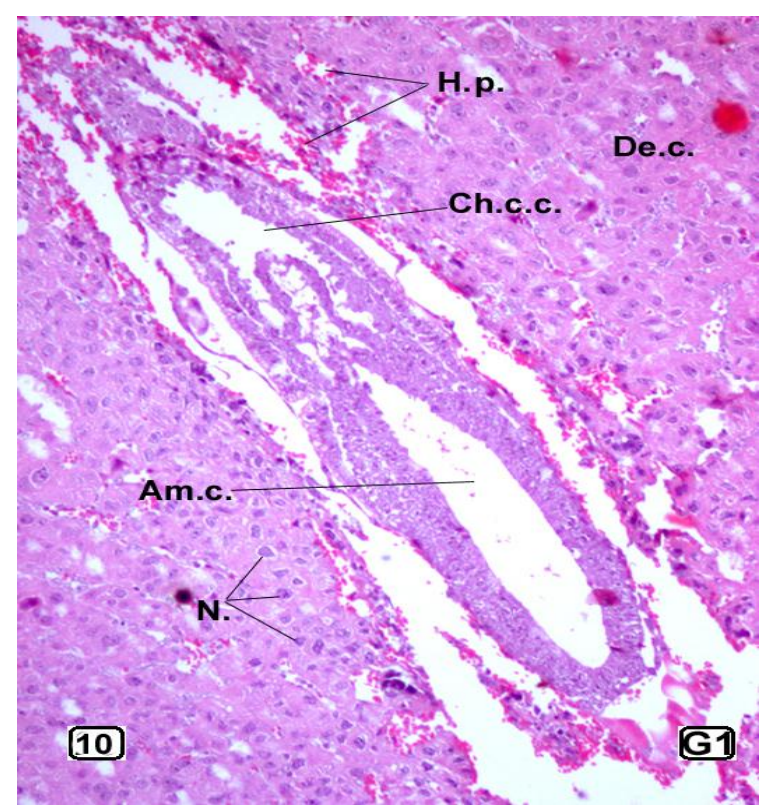

Fig. 10: Photomicrograph of a Sagittal Section Through a Cylindrical Embryo of a Mouse at 180h P.C. Treated With Low Dose of TCE Showing Retarded Embryo Which Is Differ Structurally From Normal 71/2 Day Embryo, But Consists of the Same Embryonic Layers. Note Many Decidual Cells (De.C.) with Vacuoles around Dense Basophilic Nuclei (N.), Less Developed Ectoplacental Cone (Ect.C.), Two Embryonic Cavities are Present, Ectoplacental Cone Cavity (Ch.C.C.), Amniotic Cavity (Am.C.), and Many Haemorrhagic Patches (H.P.) are Shown. The Embryo is dislodged from the Surrounding Decidua.
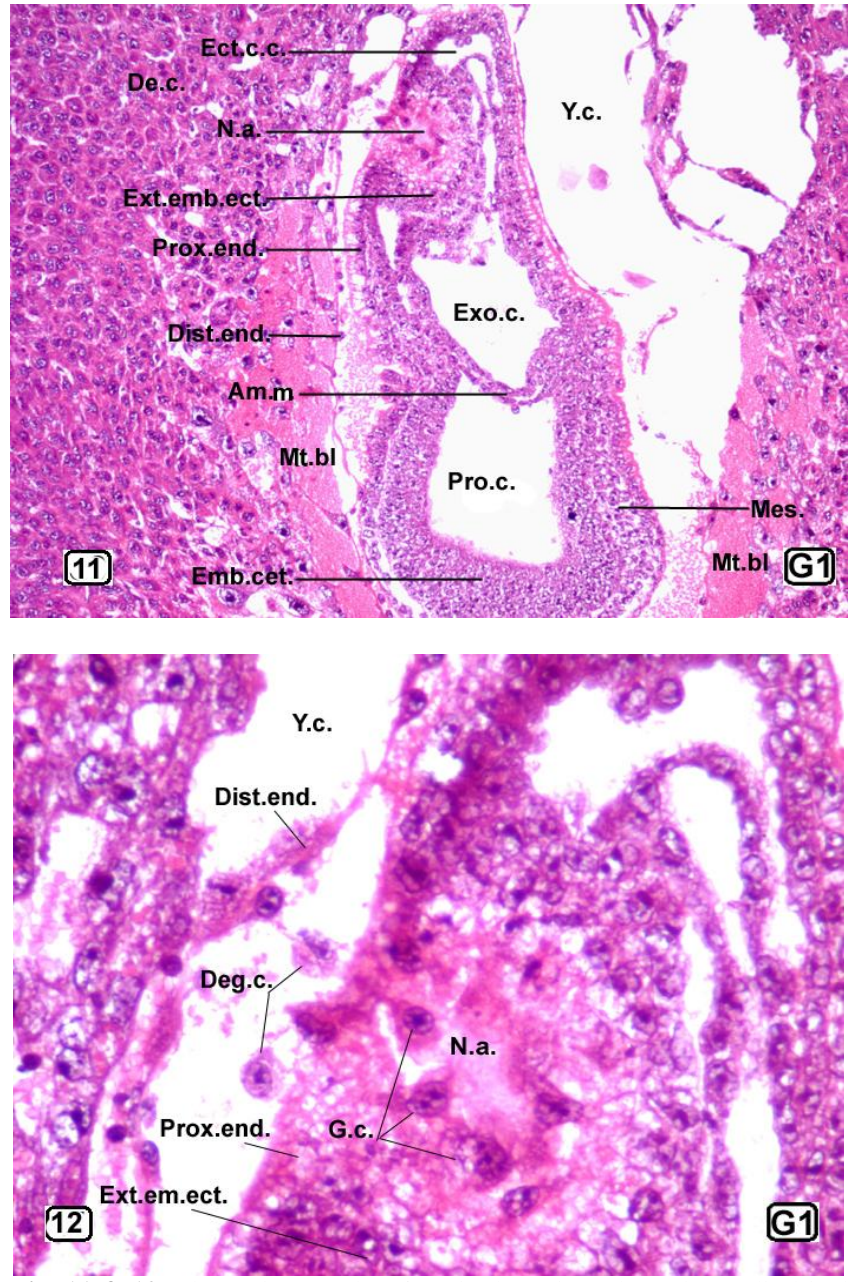

Fig. 11 \& 12: Photomicrographs of Sagittal Sections through a Cylindrica Embryo of a Mouse Treated With Low Dose of TCE Showing Retarded Embryo Consists of the Same Layers as Those of the Normal Embryo. Note Presence of A Necrotic Mass Of Cells (N.A.) In The Extraembryonic Ectoderm (Ext.Em.Ect.), Vacuolated Cells (V.C.), Giant Cells (G.C.), Degenerated Proximale Endodermal Cells (Prox.End.), Separated Dead Cells (D.C.) In The Yolk-Sac Cavity (Y.C.). Fig. 11 (X100); Fig.12 Is A Magnified Portion of Fig. 11 (X400).

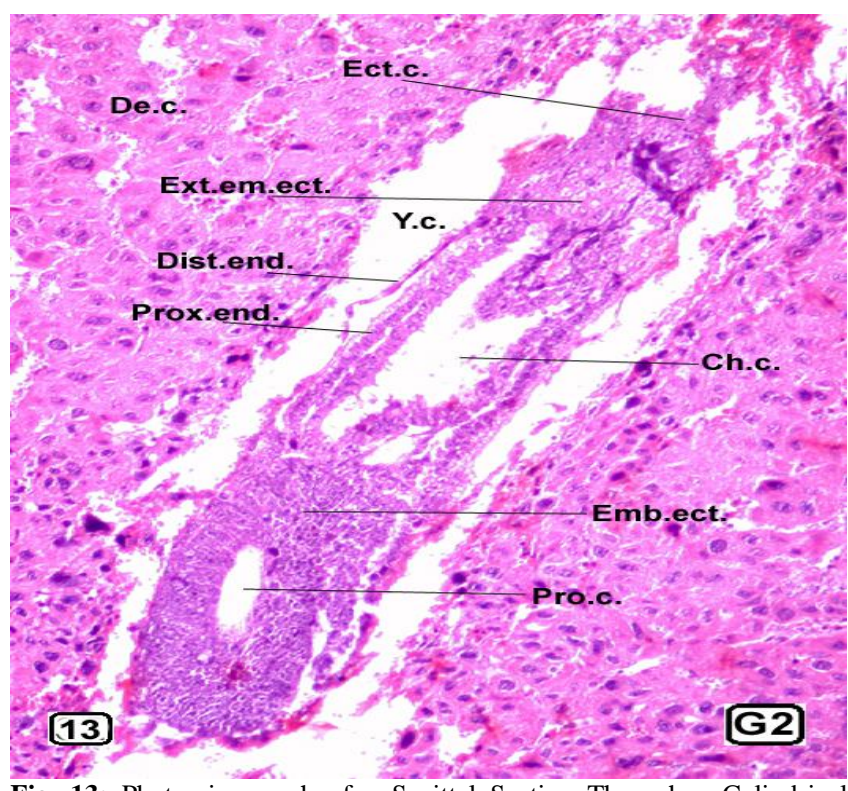

Fig. 13: Photomicrograph of a Sagittal Section Through a Cylindrical Embryo of a Mouse Treated With High Dose of TCE Showing Dislodged Retarded Embryo Consists of The Same Layers as The Control. Note Two Cavities, Ectoplacental Cone Cavity (Ch.C.C.) Within The Extraembryonic Ectoderm (Ext.Em.Ect.) and Proamniotic Cavity (Pro.C.) within the Embryonic Ectoderm (Emb.Ect.). The Decidua Shows Many Cells With Dense Basophilic Nuclei, Very Near To The Embryo. 


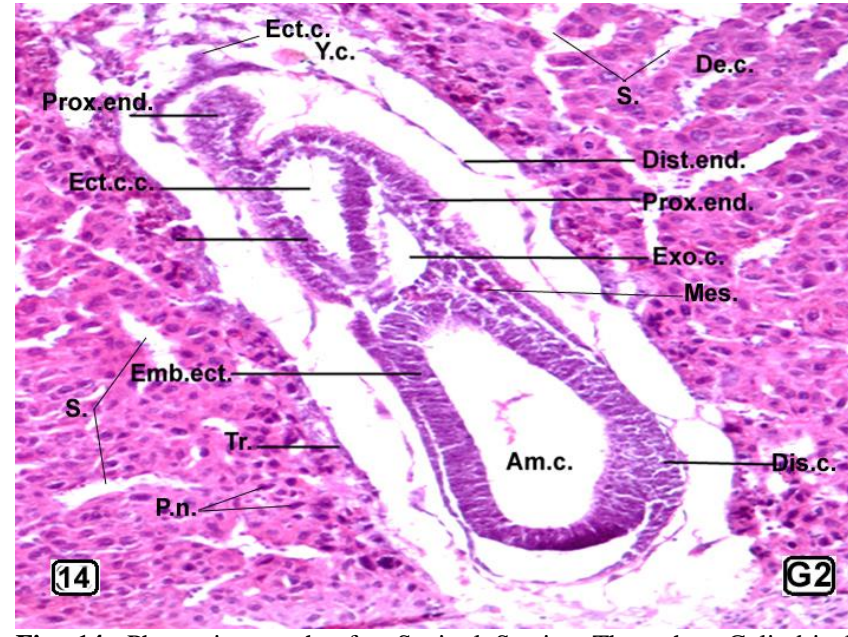

Fig. 14: Photomicrograph of a Sagittal Section Through a Cylindrica Embryo of A Mouse Treated With High Dose of TCE Showing Deformed Embryo With Undeveloped Ectoplacental Cone (Ect.C.), Disorganized Mesometrial Proximal Endoderm (D.Prox.End.), Incomplete Exocoelom (Exo.C.), and Undeveloped Mesoderm (Mes.), Unidentifiable Extraembryonic (Ext.Em.Ect.) And Embryonic Ectoderm (Emb.Ect.) Dissociated Embryonic Ectodermal Cells (Dis.C.). Note Many Decidua Cells With Pyknotic Nuclei (P.N.) And Wide Spaces (S.) In The Decidua (De.C.).

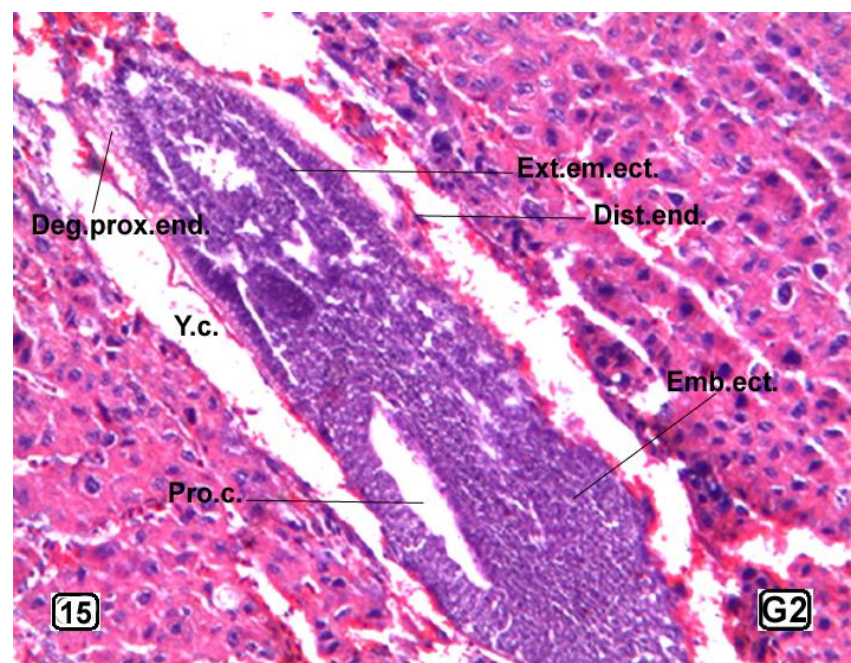

Fig. 15: Photomicrograph of a Sagittal Section Through a Cylindrical Embryo of a Mouse Treated With High Dose Of TCE Showing Degenerated Embryo Consists of a Mass of Densely Stained Cells and Two Cavities. Note Ectoplacental Cone Cavity (Ch.C.C.), Extraembryonic Ectoderm (Ext.Em.Ect.), Proamniotic Cavity (Pro.C.), Embryonic Ectoderm (Emb.Ect.), Degenerated Proximal Endoderm (Deg. Prox.End.), and Heamorrhagic Patches Around The Embryo (H.).

\section{Discussion}

\subsection{Maternal studies}

The results showed significant low increase in the body weight of non-pregnant females of G1 and G2, this was probably due to loss of appetite. In such condition, the body weight was decreased compared to the control group and proportional with the duration and level of the used dose. In addition, the pregnant dams that treated with TCE showed little increase in body weight gain throughout the three periods of experimentation. The body weight gain of TCE treated pregnant mice of group (G2) at the end of day 18 of gestation was significantly decreased compared with that of group (G1). Similar results to the current study were reported by Manson et al. (1984) who showed that rats treated with different doses of TCE prior to and throughout mating revealed a decrease in maternal body weight gain at the end of treatment (21 days). Also, Carney et al. (2006) reported that whole body inhalation exposure of pregnant rats to different concentrations of TCE caused maternal toxicity represented by statistically significant decrease $(22 \%)$ in body weight gain during the first three days of exposure to $600 \mathrm{ppm}$. In addition, Ramdhan et al. (2010) showed that exposure of male wild mice to high inhalation concentrations of TCE for 7 days caused a significant difference in body weight gain reduction compared to the control. The percent of survival was found to be $90 \%$ and $76.7 \%$ for the non-pregnant females and $95.20 \%$ and $85.7 \%$ for the pregnant females, respectively compared with $100 \%$ survival in the control group of both cases of treatment. This result was in consistent with that observed by Manson et al. (1984) who studied the effect of exposure of pregnant rats to different doses of TCE for 2 weeks $(10,100$ and 1000 $\mathrm{mg} / \mathrm{kg}$ ) prior to and throughout mating to day 21 of gestation. These authors reported an increase in maternal mortality and a decrease in neonatal survival at the high dose level of TCA. The present results showed that the percent of mating of TCE treated females for three weeks was less than the control untreated females. The percent of successful copulation was $77.8 \%$ for group (G1) that treated with the low dose and $60.9 \%$ for group (G2) that treated with the high dose compared to $96.7 \%$ for the control. These results were not in agreement with that observed by Manson et al. (1984) who reported that TCE has no effect on mating success. In addition, the present work showed abortion of pregnant females from group (G1) and group (G2) that treated with low and high doses of TCE, respectively. However, no aborted cases were observed in the control group. The percent of abortion increased from G1 to G2. These results were inconsistent with those reported by some authors (Windham et al., 1991; Taskinen et al., 1994; ATSDR, 2001). They showed that exposure to TCE increased risk of spontaneous abortion among frequently-exposed women, but disagree with the findings of other authors (Goldberg et al., 1990; Lindbohm et al., 1990; ATSDR, 2006 and 2008). These authors reported that paternal exposure to TCE has no risk of spontaneous abortion.

\subsection{Early development}

It was reported by some authors that the process of eggimplantation in the mother uterus comprised three main stages; preimplantation, implantation or attachment and adhesion stage (Potts, 1969; El-Shershaby and Hinchliffe, 1974). The present study was planned to investigate the effect of different doses of TCE (low and high doses) on pregnant mothers during implantation. The study showed some histopathological alterations in the structure of the developing embryos reaching its severity by causing degeneration of the whole embryo at this stage of early development. At this stage of development, TCE was administered to pregnant mice during the preimplantation-implantation phase of implantation where the embryos were found free in the uterine lumen or just in direct contact with the uterine epithelium (ElShershaby and Hinchliffe, 1974). The degenerated embryos observed on day six of pregnancy have lost their cylinderical form and represented by a mass of highly vacuolated dead cells with undeveloped ectoplacental cone, disorganized and unidentifiable layers with pyknotic and chromatolytic nuclei and absence of the proamniotic cavity. In addition, vacuolated decidual cell with shrinkage cytoplasm and pyknotic nuclei, (large densely stained cells probably macrophages) and wide gaps were found in the deciduama around the degenerated embryo. The deformed and degenerated embryos observed at this stage were most probably due to the effect of TCE either directly on the embryos or indirectly through the pregnant mothers. These embryos were most probably subjected latter to resorption as gestation proceeds. The most severe alterations were reported in the ectodermal mass. Since the embryonic ectodermal mass represents the embryo proper from which the mesoderm will differentiate. The present author suggested that TCE causes its adverse effects on the embryonic mass and leads to cell death. This conclusion was in accordance with that previously reported by Glucksmann (1965) and El-shershaby et al. (2006). The dead cells described in the egg-cylinder maternally treated with TCE may represent spontaneous degenerated 
cells during subsequent differentiation of the embryonic mass and cells with chromosomal abnormalities may be the source of the present dead cells. Kent (1998) reported that during development cells not only preprogrammed to replicate and differentiate, but also some cells are preprogrammed to die at specific time. According to Forsberg and Kallen (1968) these dead cells may represent cells with chromosomal abnormalities sufficient to prevent them responding to a subsequent differentiation stimulus. The present study showed that cells of different layers of the developing embryos, in normal pregnancy, were indirect contact with each other. This picture represents a kind of interaction by cell to cell contact and by production of biochemical messengers. This interaction provides a mean of coordinating the differentiation and development of various cell types within the embryo (Kent, 1998). Therefore, the death of cells as a result of exposure to toxicants may affect the normal development by disrupting the cell to cell communication. A finding which was observed in the present study that cells of the embryonic ectoderm was seen separating from each other by wide gaps.

In TCE treated pregnant dams, the retarded embryos at each doses of treatments (low and high) exhibited the form of day 7 embryos with two embryonic cavities; the proamniotic and ectoplacental cone cavity. However, the third embryonic cavity, the exocoelomic cavity, was not fully formed. The ectoplacental cone was not developed. Also, the retarded embryos showed disrupted proximal endoderm at certain regions, absence of blood islands from around the embryo, appearance of small or large hemorrhagic masses in the yolk-sac cavity and presence of many vacuolated dead cells with pyknotic nuclei in the decidual tissue. Another form of the retarded embryos was also observed, showing same structure as mentioned before, but with a necrotic mass of cells derived from the proximal endoderm and extraembryonic ectoderm that found at the abembryonic pole of the embryo. Several isolated dead cells were observed in the yolk-sac cavity together with hemorrhagic patches. This embryo may be subjected to degeneration and resorption as a gestation proceeds. Besides, treatment of pregnant mice with high dose of TCE and examined on day 8 of pregnancy showed deformed and degenerated embryos. The deformed egg-cylinder showed disorganized and disrupted embryonic ectoderm with unidentifiable cells, incomplete development of the mesoderm, a degenerated portion of the proximal endoderm at the mesometrial regionof the embryo which appeared as a protrusion in the yolk-sac cavity and absence of blood islands that observed in normal embryos. Several cracks and empty spaces were observed also in the decidual tissue. On the other hand, the degenerated embryo at this early stage of development showed very dense stained embryonic cells with dense basophilic cytoplasm and pyknotic nuclei. In such case, it was hard to distinguish the embryonic layers. Also, hemorrhagic was observed very close to the deteriorated egg-cylinder. The proximal endoderm was completely deteriorated from around the whole egg-cylinder. Disorganized decidual tissue with vacuolated cells and pyknotic nuclei were shown. Going through the literature nothing was mentioned about the effect of TCE on early embryonic development. Most studies carried out on this event delt with the effect of chemical pesticides, and other pollutants on pregnant animals and their foetuses during the late gestation period or after parturition (Howe and Webester, 1990; El-Sayyad and El-Gammal, 2001; Ebeid et al., 2011). However, other authors studied the effect of other agents on early embryos; such as 5-hydroxytreptamine (Mostafa, 1985), hypervitaminosis of vit. A (Morriss, 1973; El-Shershaby and Kaldas, 1985), the redonticide warfarin (El-Shershaby et al., 1998) and the fungicide edifenphos (El-Shershaby, et al., 2006). These studies showed some histoarcheticture alterations in early embryos of rats and mice on days 6,7 and 8 of gestation which may lead to embryolethality and resorption. The present study showed some deformed and degenerated embryos on days 6 and 8 of pregnancy maternally treated with TCE. It was suggested that the degenerated embryos observed at early pregnancy represent resorped embryos observed at the end of gestation. Howe and Webester (1990) revealed that warfarin intoxication to pregnant rats caused resorption of all implants and produced injurious effects on the growing blastocyst when giving during the first trimester. Also, low and high doses of DUAL $(367.9 \mathrm{mg} / \mathrm{kg}$ and $1103.8 \mathrm{mg} / \mathrm{kg}$ ) increased the percent of preimplantation and postimplantation losses to $66.7 \%$ and $58.9 \%$ for the two doses, respectively. In addition, several studies showed several alterations in the histoarchitecture of the developing embryos at early stages of pregnancy under the effect of different substances. In addition, Collins et al. (1981 \& 1983) showed that caffeine decreased implantation efficiency and might cause developmental failure in embryos at earlier stages of development. Therefore, it was suggested that TCE treatment with the high dose for five or six successive days (1-5 or 1-6) of pregnancy caused teratogenic changes in the histoarchitecture of the egg-cylinder leading to embryolethality and resorption.

\section{Conclusions}

The results obtained from embryos of days 6 and 8 of pregnancy showed that TCE has embryotoxic and teratogenic effects on postimplantation embryos and the degree of these effects dependents upon the level and duration of the dose. Whereas, the sever effects appeared in G2 more than that of G1 in contrast with the control group.

\section{Acknowledgement}

The authors would like to thank the head of Zoology Department, Faculty of Science, Benha University, for the help offered me through the preparation of this manuscript.

\section{References}

[1] ATSDR (Agency for Toxic Substances and Disease Registry). (2001), Final Report, Evaluation of priority health conditions in a community with historical contamination by trichloroethylene. Atlanta, GA: U.S Department of Health and Human Services.

[2] ATSDR (Agency for Toxic Substances and Disease Registry). (2008), Health consultation: Health statistics review follow-up: Cancer and birth outcome analysis, Endicott area investigation, Endicott area, Town of Union, Broome County, New York. Atlanta, GA: U.S. Department of Health and Human Services.

[3] Carney E, Thorsrud B, Dugard P \& Zablotny C (2006), Developmental toxicity studies in $\mathrm{Crl}: \mathrm{CD}(\mathrm{SD})$ rats following inhalation exposure to trichloroethylene and perchloroethylene. Birth Defects Res. Dev. Reprod. Toxicol. 77, 405-412.

[4] Collins TFX, Welsh J, Black T \& Collins E (1981), A study of the teratogenic potential of caffeine in rats when given by oral intubation. Regul. Toxicol. Pharmacol., 1, 355-378.

[5] Collins TFX, Welsh J, Black T \& Reggles DI (1983), A study of the teratogenic potential of caffeine ingested in drinking water. Food Chem. Toxicol., 2(6), 673-777.

[6] Dallas CE, Gallo JM, Ramanathan R, Muralidhara S \& Bruckner JV (1991), Physiological pharmacokinetic modeling of inhaled trichloroethylene in rats. Toxicol. Appl. Pharmacol., 110, 303-314.

[7] De-Baere S, Meyer E, Dirinck I, Lambert W, Piette M, VanPeteghem C \& De-Leenheer A (1997), Tissue distribution of trichloroethylene and its metabolites in a forensic case. Anal. Toxicol. 21, 223-227.

[8] Ebeid HM, Mollal ME \& El-Rayess RA (2011), Experimental studies on the effect of lead acetate on pregnant mice and their fetuses. J. Egypt. Ger. Soc. Zool., 63 (B), 25-41.

[9] El-Sayyad HI \& El-Gammal HL (2001), Effects of ethylene glycol monomethyle ether on prenatal development of rats. J. Egypt. Ger. Soc. Zool., 35(B), 59-76.

[10]El-Shershaby AM, El-Ganzuri MA \& Kandeel AA (2006), Teratogenic and embryolethal effects of edifenphos during early pregnancy in mice. J. Union Arab Biol. Cairo, 25(A), 67-87.

[11]El-Shershaby AM, Kaldas SK \& El-Halawany MS (1998), Teratogenic effects of warfarin on the rat embryos during early pregnancy: Histological and cytological studies. J. Egypt. Ger. Soc. Zool., 25(B), 1-24. 
[12]El-Shershaby AM, El-Ganzuri MA \& Kandeel AA (2006), Teratogenic and embryolethal effects of edifenphos during early pregnancy in mice. J. Union Arab Biol. Cairo, 25(A), 67-87.

[13]El-Shershaby AM \& Hinchliffe JR (1974), Cell redundancy in the zona intact. Preimplantation mouse blastocyst: A light and electron microscope study of dead cells and their fate. J. Embryol. Exp. Morphol., 31(3), 646-654.

[14]El-Shershaby AM and Kaldas SK (1985), Teratogenic effect of vitamin A on early embryo of the rat: A histological study. J. Histol., 8(2), 165-174.

[15]Fernandez JG, Droz PO, Humbert BE \& Caperos JR (1977), Trichloroethylene exposure simulation of uptake, excretion, and metabolism using a mathematical model. Br. J. Ind. Med., 34, 43-55.

[16]Fisher JW, Gargas ML, Allen BC \& Andersen ME (1991), Physiologically based pharmacokinetic modeling with trichloroethylene and its metabolite, trichloroacetic acid, in the rat and mouse. Toxicol. Appl. Pharmacol., 109, 183-195.

[17]Forsberg JG \& Kallen B (1968), Cell death during embryogenesis. Rev. Roum. dEmbryol. Cytol, 5(2), 91-102.

[18]Glucksmann A (1965), Cell death in normal development. Arch. Leig. Rev., 76(3), 419-437.

[19]Goeptar AR, Commandeur JM, Van-Ommen B, Van-Bladeren PJ \& Vermeulen NE (1995), Metabolism and kinetics of trichloroethylene in relation to toxicity and carcinogenicity. Relevance of the mercapturic acid pathway. Chem. Res. Toxicol., 8, 3-21.

[20]Goldberg S, Lebowitz M, Graver E \& Hicks S (1990), An association of human congenital cardiac malformations and drinking water contaminants. J. Am. Coll. Cardiol., 16, 155-164.

[21] Howe AM \& Webster WS (1990), Exposure of pregnant rat to warfarin and vitamin $\mathrm{K}, 1$ : An animal model of intraventricular hemorrhage in the fetus. Teratology, 42, 413-420.

[22]IARC (International Agency for Research on Cancer). (1995), Trichloroethylene. In IARC Monograph on the Evaluation of the Carcinogenic Risk of Chemicals to Humans. 63, 75-158.

[23] Kaneko T, Wang PY \& Sato A (1997), Assessment of the health effects of trichloroethylene. Ind. Health, 35, 301-324.

[24]Kent C (1998), Teratogens. In: Basics of toxicology. Eds. Jhon Wiley \& Sons Inc.

[25]Lash LH, Parker J \& Scott C (2000), Modes of action of trichloroethylene for kidney tumorigenesis. Environ. Health Perspect., 108(2), 225-240.

[26]Lindbohm M, Taskinen H, Sallmen M \& Hemminki K (1990), Spontaneous abortions among women exposed to organic solvents. Am. J. Ind. Med., 17, 449-463.

[27]Manson J, Murphy M, Richdale N \& Smith M (1984), Effects of oral exposure to trichloroethylene on female reproductive function. Toxicology, 32, 229-242.

[28]Maull EA, Cogliano VJ, Scott CS, Barton HA, Fisher JW, Greenberg M, Rhomberg L \& Sorgen SP (1997), Trichloroethylene health risk assessment: A new and improved process. Drug Chem. Toxicol., 20, 427-442.

[29]Mitoma C, Steeger T, Jackson SE, Wheeler KP, Rogers JH \& Milman HA (1985), Metabolic disposition study of chlorinated hydrocarbons in rats and mice. Drug Chem. Toxicol., 8, 183-194.

[30]Morris, GM (1973), An electron microscopic study of the effects of hyper vitaminosis A on the maternal and embryonic relationship of the rat at 8 days of pregnancy. J. Reprod. Fertil., 33, 451-456.

[31]Mostafa, EM (1985), Studies on some factors affecting implantation in some experimental animals. Ph.D. Thesis, Fac. Med. Assiut Univ.

[32]Potts DM (1969), The ultrastructure of egg implantation. Adv. Reprod. Physiol., 4, 241-267.

[33]Prout, MS, Provan WM \& Green T (1985), Species differences in response to trichloroethylene. Pharmacokinetics in rats and mice. Toxicol. Appl. Pharmacol., 79, 389-400.

[34]Ramdhan D, Kamijima M, Wang D, Ito Y, Naito H, Yanagiba, Y, Hayashi Y, Tanaka N, Aoyama T, Gonzalez F \& Nakajima T (2010), Differential response to trichloroethylene-induced hepatosteatosis in wild-type and PPARalpha-humanized mice. Environ. Health Perspect., $118,1557-1563$.

[35]Rouisse L \& Chakrabarti SK (1986), Dose-dependent metabolism of trichloroethylene and its relevance to hepatotoxicity in rats. Environ. Res., 40, 450-458.

[36] Taskinen H, Kyyronen P \& Hemminki K (1994), Laboratory work and pregnancy outcome. J. Occup. Med., 36, 311-319.

[37]Ugden PC \& Miller JW (1983), Chlorinated acids and chloral in drinking water. J. Am. Water Works Assoc., 75, 524 -527.

[38] Windham G, Shusterman D, Swan S, Fenster L \& Eskenazi B (1991), Exposure to organic solvents and adverse pregnancy outcome. Am. J. Ind. Med., 20, 241-259. 